\title{
Petrophysical Charaterization of the Kwale Field Reservoir Sands (OML 60) from Wire-line Logs, Niger Delta, Nigeria.
}

\author{
EKINE, A. S.; IYABE, PAUL
}

Department of Physics, University of PortHarcourt, PortHarcourt, Nigeria.

\begin{abstract}
Well log data from the deep parts of the six wells located in the Kwale field of the Niger delta basin (OML 60) were used in the determination of some Petrophysical characteristics of the reservoir sands. Well $\log$ data were obtained from sonic, gamma-ray, matrix density and resistivity logs. The petrophysical characteristics investigated were porosity, water saturation and permeability. The results of the analysis revealed the presence of twelve sand units. Correlation of these sand bodies indicate that the reservoirs consist of stacked barrier bar and point-bar sandstones. The thickness of each sand unit is highly variable, ranging between 5.0 and $95.0 \mathrm{~m}$. Average shale-corrected porosities vary between 11.0 and 19.0 percent and generally decreasing with depth. The average water saturation of these units vary between 52.5 and 88.5 percent. These values are generally high for the sand units in wells 2, 5, 6 and 8 . Similarly, the average permeability values vary between 3.2 and 28.0 $\mathrm{mD}$. This study is a first attempt to make available Petrophysical data for the reservoir sands in the Kwale field of the Niger delta basin. The results of this study will also enhance the proper characterization of the reservoir sands. However, other sources of confirmative and collaborative investigations will therefore be essential and consequently will be the focus of another study @ JASEM
\end{abstract}

Petrophysical logs interpretations used for the characterization of reservoir sands are very useful and important tools for selecting, planning and implementing operationally sound supplementary recovery schemes. These logs are commonly used in exploration for the correlation of sand bodies, isopach and structural mappings, and for the determination of certain physical properties of rocks such as porosity, permeability, lithology identification and possibly pore geometry. The evaluation of reservoir rocks in terms of their porosity, water saturation and permeability determinations, enhances the ability to predict abnormally pressured zones, to estimate hydrocarbon reserves and reservoir bed thickness, and to distinguish between gas, oil and water bearing strata, by observing their electrical resistivity and relative permeability values (Hilchie, 1990; Schlumberger, 1996; Uguru et al., 2002). The dearth of published works on the petrophysical characteristics of reservoir rocks in the Niger delta complex prompted the interest in this work. This study, therefore attempts to correlate the reservoir sands encountered by six deep wells in the Kwale field (OML 60) (see Fig. $1)$; using their porosity, water saturation and permeability values as petrophysical parameters.

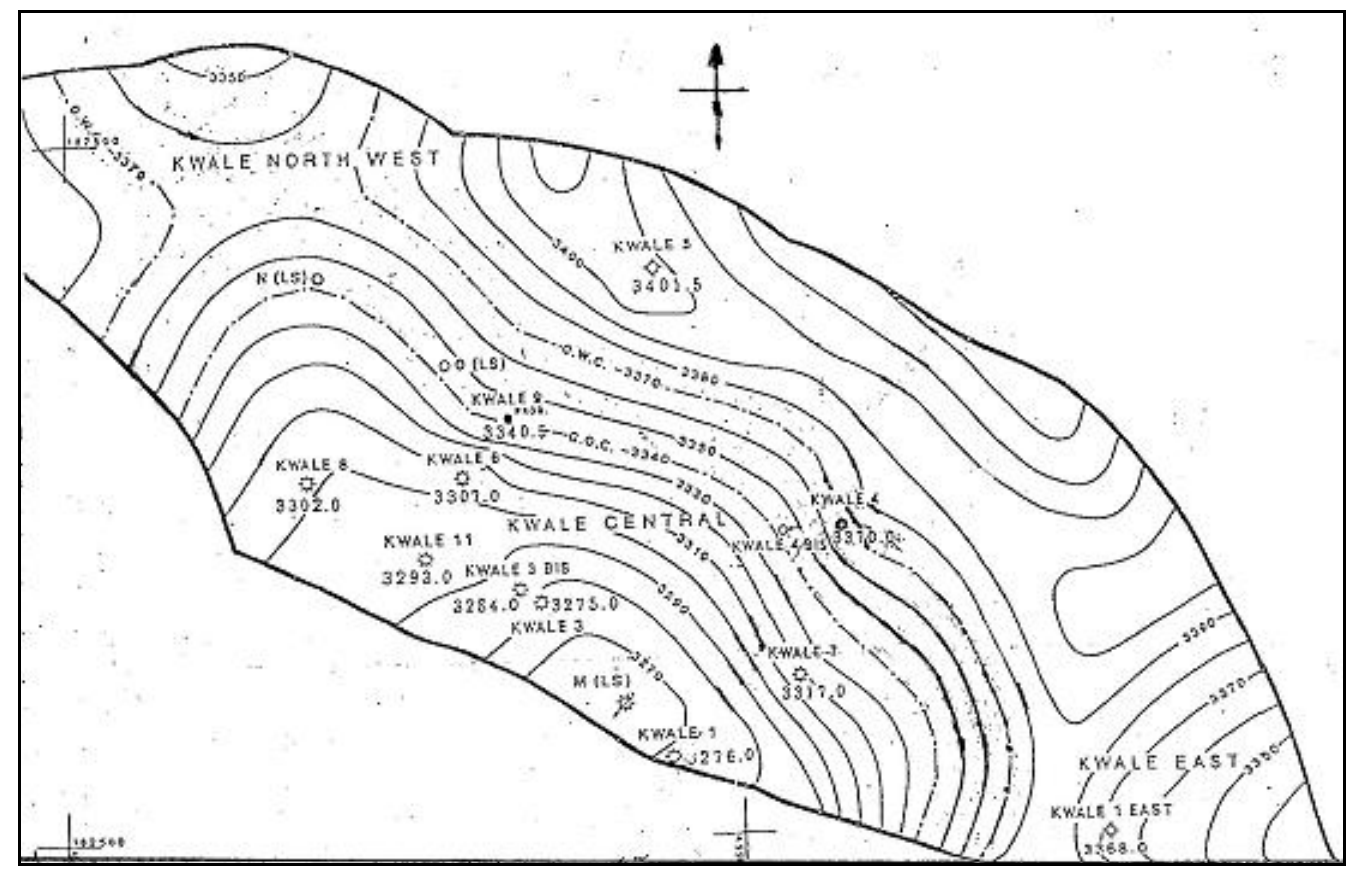

Fig 1. Map of Study Area Showing Locations of Various Wells 
Summary of the Structural and Stratigraphic Setting of the Study Area: The study area, located within the northwestern parts of the Niger delta complex, is characterized by structures which resulted from listric growth faults and their associated roll-ever anticlines (Fig. 2). An antisymmetrical roll-over anticline bounded on the northeast and southwest by a major southwest dipping listric fault comprises the major structure in this area. A minor synthetic fault extends from the western to the southern boundary forming structural closure to the west of the Kwale block. Three different highs exist in the area namely a central high where most of the wells have been drilled; an eastern high housing one well; and a northwestern high whose extent has not been clearly defined. A saddle separating the central from the northwestern high is shifted towards the south. (Mamosa, 1972; Ashaka and Mamosa, 1972). The stratigraphic sequence of the Cenozoic Niger delta complex has been discussed in great details in several works which include Short and Stauble (1967); Allen (1972); Merki (1972); Murat
(1972); Avbovbo and Ogbe (1978). The sandstones of the Agbada Formation represent the major hydrocarbon reservoirs in the Kwale field.

\section{METHOD OF ANALYSIS}

Well log data from sonic, gamma ray, matrix density and resistivity logs from six deep wells in the Kwale field (OML 60) were used in the analysis. These logs were acquired by Schlumberger for Nigeria Agip Oil Company Limited. The ability of rocks to conduct electrical current is primarily a function of the quantity and salinity of the pore fluid. A highly resistive permeable bed is therefore indicative of high hydrocarbon saturation (Dresser Atlas, 1982). The resistivity logs were therefore first used to identify hydrocarbon or water-bearing zones and hence indicate permeable zones. The various sand bodies were then identified on the gamma ray logs. From these $\operatorname{logs}$ also were determined the gamma ray index $\mathrm{I}_{\mathrm{GR}}$ needed for the computation of shale volume in the identified sand bodies.

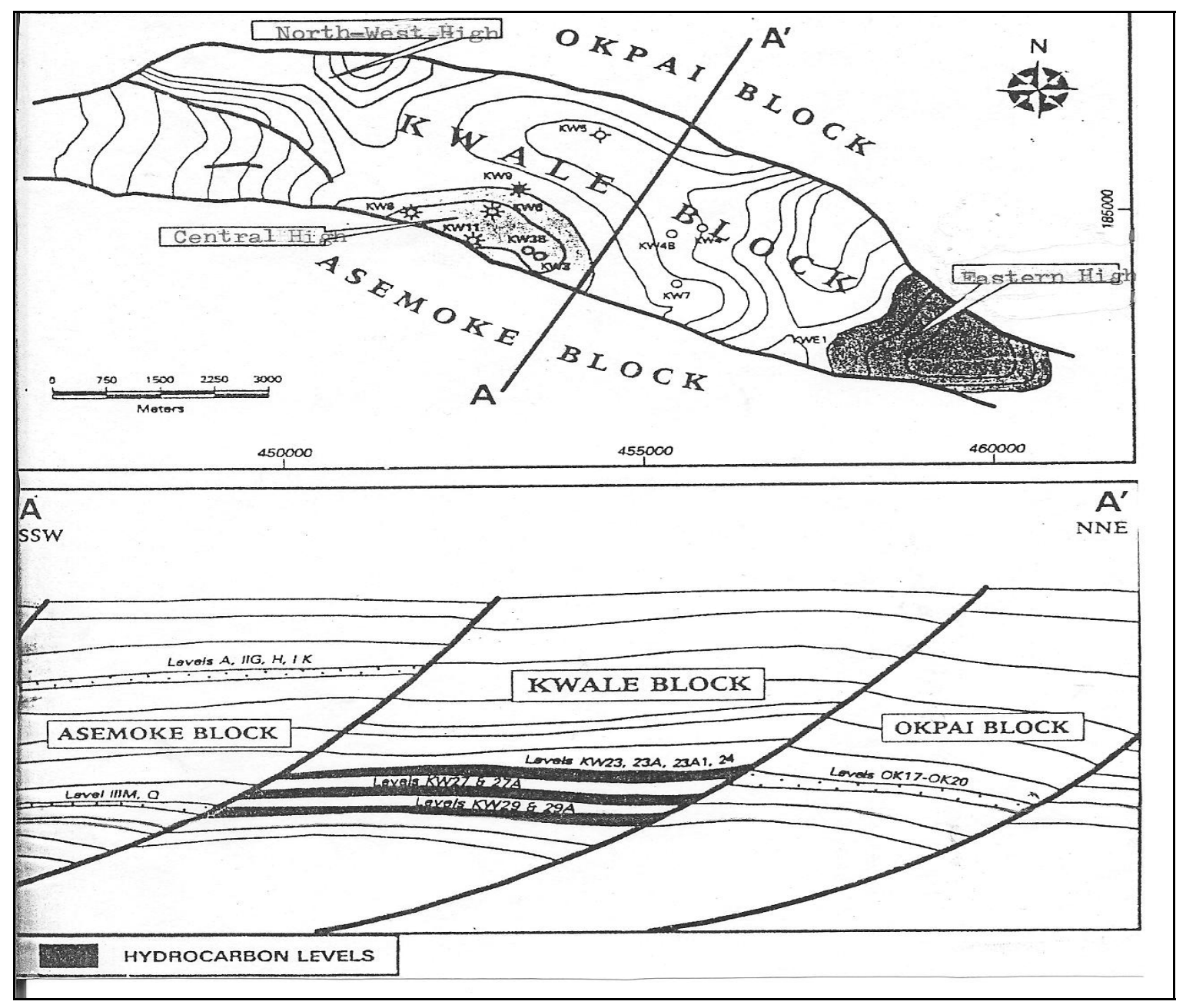

Fig 2. Structural setting of the Kwale field (after Mamosa, 1972)

* Corresponding author: Ekine, A. S. 
Using the bulk density and sonic logs, the shale corrected $\Phi_{c c}$ of the sand bodies were estimated using the following relations: -

$$
\begin{gathered}
\emptyset_{c c}=\frac{\Delta t-\Delta t_{m a}}{\Delta t_{f}=\Delta t_{m a}}-V_{s h}\left(\frac{\Delta t_{s h}-\Delta t_{m a}}{\Delta t_{f}-\Delta t_{m a}}\right) \\
\emptyset_{c c}=\frac{P_{m a}-P_{b}}{p_{m a}-P_{f}}-V_{s h}\left(\frac{\rho_{m a}-P_{s h}}{\rho_{m a}-P_{f}}\right)
\end{gathered}
$$

where $\Delta \mathrm{t}=$ formation interval transit time; $\Delta \mathrm{t}_{\mathrm{ma}}=$ formation matrix interval transit time; $\Delta \mathrm{t}_{\mathrm{sh}}=$ inte $^{\mathrm{r}}$ val transit time for adjacent shale; $\Delta \mathrm{t}_{\mathrm{f}}=$ interval transit time for interstitial fluid $=189 \mu \mathrm{s} / \mathrm{ft}$; $\rho_{\mathrm{ma}}=$ matrix bulk density $=2.65$ gm- $\mathrm{cm}^{-3} ; \rho_{\mathrm{b}}=$ formation bulk density; $\rho_{\mathrm{f}}=$ fluid density $=1.01$ $\mathrm{gm}-\mathrm{cm}^{-3}$; and $\rho_{\mathrm{sh}}=$ bulk density of adjacent shale. The shale volume $V_{s h}$ in the sand bodies was estimated using the equation (3) below which is valid particularly for Tertiary sediments.

$$
\begin{aligned}
& V_{\text {sh }}=0.03\left(2^{3 \pi} I_{G R}\right) \\
& \text { where }{ }_{G R}=\frac{G R_{\log }-6 R_{\min }}{G R_{\text {max }}-G R_{\min }}
\end{aligned}
$$

and $\mathrm{GR}_{\log }=$ gamma-ray log value for shaley sand; $\mathrm{GR}_{\min }=$ gamma-ray minimum value for clean sand; and $\mathrm{GR}_{\max }=$ gamma-ray maximum value for shale zone

To estimate the formation water saturation $S_{w}$, the true formation resistivity $\mathrm{R}_{\mathrm{t}}$ from the deep reading resistivity $\log$ is first obtained and the formation water resistivity as supplied by the company noted.
Then using the modified Archie's equation (5) (Dresser Atlas, 1982) we have that

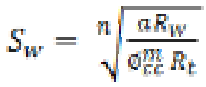

where $\mathrm{R}_{\mathrm{w}}=$ resistivity of formation water; $\mathrm{a}=$ tortuosity $=0.81 ; \mathrm{m}=$ cementation factor $=2.0$ and $\mathrm{n}=$ saturation exponent usually taken as 2.0.

A formation is at its irreducible water saturation when its bulk volume water $B_{v w}$ is constant. This value is obtained from equation (6) below.

$$
b_{w}=s_{w} \sigma_{c}
$$

At the irreducible water saturation, the Timur's equation is applied to determine the formation permeability $\mathrm{K}$, which is given as

$$
K_{(m D)}=\frac{0.13 a d c^{4}}{z_{w}^{2}}
$$

The results obtained from these computations are presented on Tables 1,2 and 3. By applying the characteristic log motif techniques after Selley (1976), the resistivity and gamma ray curves were used to correlate the sand bodies. The porosity values were also incorporated in the process of correlation. The sand bodies identified are labeled from $A$ to $M$ as indicated. A typical sand development trend (isopach map) for sand unit $G$ is shown on Figure 3.

Table 1: Lateral Distribution of Porosity Values in the Sands (\%)

\begin{tabular}{lllllll}
\hline Sands & Kwale-1 & Kwale-2 & Kwale-5 & Kwale-6 & Kwale-8 & Kwale-10 \\
\hline A & - & 21 & 19 & - & - & 17 \\
B & 19 & 18 & 19 & 19 & - & 17 \\
C & 21 & 19 & 19 & 17 & - & - \\
D & 20 & 20 & 18 & 17 & - & 18 \\
F & 17 & 18 & 17 & 17 & 15 & 17 \\
G & 17 & 19 & 17 & 17 & 13 & 16 \\
H & 17 & 17 & 11 & 16 & 13 & - \\
I & - & 16 & 17 & 15 & 12 & - \\
J & - & 16 & 14 & 14 & 12 & - \\
K & - & 19 & 13 & 13 & 12 & - \\
L & 16 & 17 & 13 & 11 & - & - \\
M & 14 & - & 11 & 12 & 13 & - \\
\hline
\end{tabular}

Table 2: Lateral Distribution of Water Saturation $\left(\mathrm{S}_{\mathrm{w}}\right)$

\begin{tabular}{lllllll}
\hline Sands & Kwale-1 & Kwale-2 & Kwale-5 & Kwale-6 & Kwale-8 & Kwale-10 \\
\hline A & - & 74 & - & - & - & 31 \\
B & 45 & 75 & 69 & 76 & - & 39 \\
C & 32 & 82 & 77 & 71 & - & - \\
D & 48 & 85 & 73 & 74 & - & 49 \\
F & 53 & 93 & 78 & 69 & - & 52 \\
G & 50 & 75 & 82 & 74 & - & 63 \\
H & 36 & 91 & 89 & 67 & 76 & - \\
I & - & 75 & 71 & 63 & 92 & - \\
J & - & 82 & 90 & 90 & 92 & - \\
K & - & 75 & 74 & 73 & 92 & - \\
L & 41 & 81 & 66 & 81 & 58 & - \\
M & 57 & - & 51 & 55 & 54 & - \\
\hline
\end{tabular}


Table 3: Lateral Distribution of Permeability K (Md)

\begin{tabular}{lllllll}
\hline Sands & Kwale-1 & Kwale-2 & Kwale-5 & Kwale-6 & Kwale-8 & Kwale-10 \\
\hline A & - & 16 & - & - & - & 37 \\
B & 28 & 8.1 & 12 & 10 & - & 23 \\
C & 87 & 8.6 & 9.4 & 7.0 & - & - \\
D & 31 & 10 & 10.8 & 6.4 & - & 24 \\
F & 16 & 5.2 & 9.4 & 7.4 & - & 13 \\
G & 18 & 8.1 & 5.2 & 7.4 & - & 68 \\
H & 27 & 4.3 & 5.2 & 6.0 & 1.9 & - \\
I & - & 4.8 & 6.5 & 5.1 & 1.1 & - \\
J & - & 4.0 & 6.9 & 1.8 & 1.1 & - \\
K & - & 10.2 & 1.8 & 2.0 & 1.1 & - \\
L & 16 & 5.4 & 1.9 & 0.8 & 2.3 & - \\
M & 4.6 & - & 1.9 & 2.5 & 3.7 & - \\
\hline
\end{tabular}

\section{RESULTS AND DISCUSSION}

Results of the analysis identified a total of twelve reservoir sands which have been from $\mathrm{A}$ to $\mathrm{M}$ without $\mathrm{E}$. These identifications were based on the characteristic log motifs after Selley (1976). Sand bodies $\mathrm{B}, \mathrm{D}, \mathrm{F}, \mathrm{I}, \mathrm{K}$ and $\mathrm{M}$ have the character of blocky or funnel-shaped curves and are serrated which are representative of upward flaring $\log$ expression. These sand units can be interpreted as barrier bar sands. Sand units A, C, G, H, J and L are interpreted as point bar or channel sandstones because of their characteristic upward narrowing or bell-shaped log expression exhibited by sandstones which fine upwards. Some of the sand units were encountered in all the wells (such as units F and G), whereas most others could not be identified because of non-availability of some sections of the analyzed well logs, particularly for wells 8 and 10 . All the sand units encountered consist of stacked barrier bar sands or point bar sandstones with continuous shaley interbeddings throughout the field. Porosities within the field are observed generally to decrease with depth. The estimated average porosity value range between 19.0 and 13.0 percent decreasing with depth. These low porosity values may be attributed to mainly grain size and sorting effects within the reservoir sands (Pickett, 1960; Beard and Weyl, 1973 and Scherer, 1987). All the sand units investigated are confined within the Agbada Formation. The varying shale contents and the depths of burial may have contributed, though to a minor extent, to the decrease in porosity. The porosity values are however considered to be fairly good for hydrocarbon accumulation.

Average water saturation of the sand units vary between 52.5 and 88.5 percent. These average water saturation values are observed to increase with depth from unit a to a maximum in unit $\mathbf{J}$ at the average depth of about 3,300 $\mathrm{m}$. These values then decrease to about 54.0 percent within $\mathrm{M}$. The estimated water saturation values are also observed to be generally high for the sand units in wells 2,5 , 6 and 8. Owing to the fact that no other form of analysis was undertaken to support the results of this work, we could not advance specific causes for the trend in the water saturation values. However, the differences layer clay content and slight differences in the exchangeable hydrated cations in these clays (Timur, 1968; Dresser Atlas, 1882). The average permeability values for the various sand units vary between 3.2 and $28.0 \mathrm{mD}$. These values are observed to decrease with depth, with the exception of units $\mathrm{C}$ and $\mathrm{G}$. Permeability values are generally high for all the sand units in wells 1 and 10 with ranging between 13.0 and $87.0 \mathrm{mD}$. However, the sand units in wells 2, 5, 6 and 8 have permeability values that are below $10.0 \mathrm{mD}$, which is agreement with the variations in water saturation values obtained for these wells. This effect is as a result of micropores in the sand units which are preferentially water-wet. Some of these units that are relatively thin could act as secondary trapping mechanism. The thicknesses of the sand units are highly variable, becoming thinnest around units A, $\mathrm{C}, \mathrm{H}$ and $\mathrm{J}$ with thicknesses of between 5.0 and $25.0 \mathrm{~m}$. The next groups are units B, D, G, I, K and $\mathrm{L}$ which are relatively thick and having thicknesses between 10.0 and $55.0 \mathrm{~m}$. The thickest sand units are units $\mathrm{F}$ and $\mathrm{M}$ with thicknesses between 45.0 and $95.0 \mathrm{~m}$. Sand unit $\mathrm{G}$, which is encountered in all wells, has the thickest sand development of about $55.0 \mathrm{~m}$ around well 6 and thins in a southeasterly direction towards well 2 with a thickness of about $10.0 \mathrm{~m}$. 


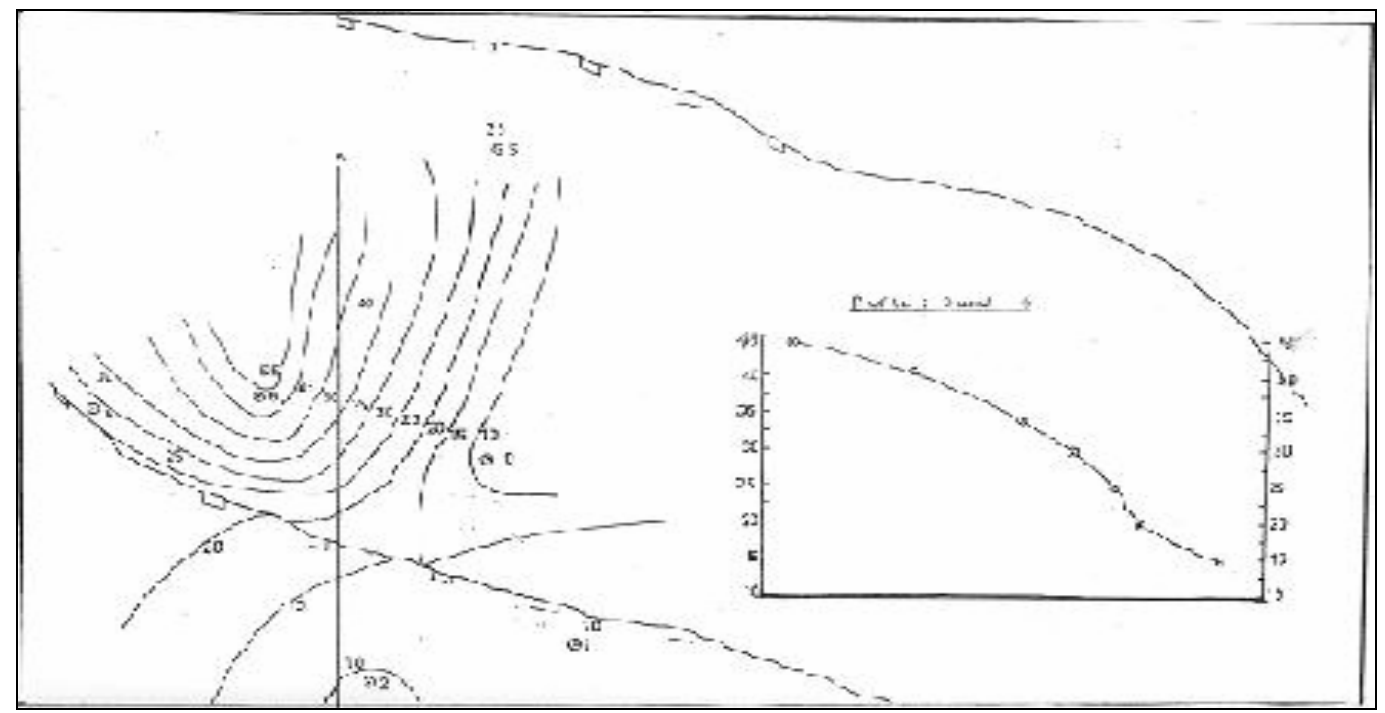

Fig. 3: Isopach map sand unit $G$

The above correlations and interpretations have been arrived at through well logs analysis only. The need for other sources of confirmative and collaborative data, such as drill stem test, core analysis and production data are highly imperative. The results from these data will technically enhance the proper characterization of the reservoir sands. However, the proposed data set is currently highly classified.

\section{REFERENCES}

Allen, JR, (1964). The Nigerian continental margin bottom sediments: Submarine morphology and geological evolutions. Marine Geology, 1: 289 -323 .

Ashaka, P; Mamosa, S (1972). Agip deep drilling technology. Oil and gas Journ., 5: $1-15$.

Avbovbo, AA; Ogbe, FG (1978). Tertiary lithostratigraphy of the Niger delta. A. A. P. G Bull., 62: $285-300$.

Beard, DC; Weyl, PK (1973). Influence of texture on porosity and permeability of unconsolidated sands. A. A. P. G. Bull., 57; 349 - 369.

Dresser Atlas, (1982). Well-logging and interpretation techniques. Dresser Industries Inc.

Hilchie, DW (1990). Wireline: A history of the well logging and perforation business in the oil fields. D. W. Hilchie Inc., Boulder, Colorado, U. S.A. pp. $25-86$.

Mamosa, S (1972).. Geology of the Kwale field. Unpublished paper for Nigeria Agip Oil Company.
Merki, P (1972). Structural geology of the Cenozoic Niger delta. In African Geology, eds. T. J. F. Dessauvagie and A. J. Whiteman, University of Ibadan Press. Pp. $251-268$.

Murat, RC (1972). Stratigraphy and paleogeography of the Cretaceous and Lower Tertiary in Southern Nigeria. In African Geology, ed. T. J. F. Dessauvagie and A. J. Whiteman, University of Ibadan Press. Pp. 635 -648 .

Pickett, E (1960). The use of acoustic logs in the evaluation of sandstones reservoir. Geophysics, 21(\#3): $250-274$.

Scherer, M (1987). Parameters influencing porosity of sandstones: A model for sandstone porosity prediction. A. A. P. G. Bull., 71: 485 - 491.

Schlumberger, (1972). Log interpretations. Schlumberger Inc., New York. 2: 112 - 116.

Schlumberger, (1996). Log interpretation charts. Schlumberger Well Services, Houston. Pp. 2 34.

Selley, RC (1976). Subsurface environmental analysis of North Sea sediments. A. A. P. G. Bull., 60: $184-190$.

Timur, A (1968). An investigation of permeability, porosity and residual water saturation relationships for sandstone reservoirs. The Log Analyst, July - August, 9(\#4): 3 - 5.

Uguru, CI; Onyeagoro, OU; Sikiru, IO (2002). Permeability modeling for reservoirs in the Niger Delta based on geological descriptions and core data. SIPM Review Report, pp. $4-$ 98. 